\title{
PREPARASI DAN KARAKTERISASI KOMPOSIT KITOSAN-ZnO/ $\mathrm{Al}_{2} \mathrm{O}_{3}$ PREPARATION AND CHARACTERIZATION OF CHITOSAN-ZnO/Al $\mathrm{O}_{2}$ COMPOSITE
}

\author{
Dina Kartika Maharani*, Rusly Hidayah \\ Jurusan Kimia FMIPA Universitas Negeri Surabaya \\ *email:dkmaharani@gmail.com ${ }^{1}$
}

\begin{abstract}
ABSTRAK
Penelitian ini memiliki tujuan untuk menghasilkan material komposit baru berbasis bio polimer dan material anorganik non toksik yang dapat diaplikasikan pada berbagai bidang salah satunya pada industri tekstil sebagai agen antibakteri melalui proses pelapisan atau coating pada kain. Komposit kitosan- $\mathrm{ZnO} / \mathrm{Al}_{2} \mathrm{O}_{3}$ dipreparasi melalui pencampuran larutan

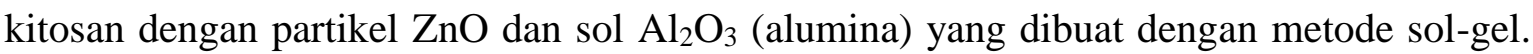
Karakterisasi komposit dilakukan menggunakan metode spektrofotometri FTIR (Fourier Transform Infra Red) dan XRD (X-Ray Diffraction). Hasil penelitian menunjukkan bahwa komposit kitosan- $\mathrm{ZnO} / \mathrm{Al}_{2} \mathrm{O}_{3}$ yang dihasilkan berupa larutan yang jernih dan transparan sehingga sangat sesuai untuk proses pelapisan tekstil sebagai agen fungsional antibakteri pada tekstil. Karakterisasi FTIR komposit menunjukkan telah terjadi interaksi antara gugus fungsi pada kitosan dengan $\mathrm{ZnO}$ dan $\mathrm{Al}_{2} \mathrm{O}_{3}$ pada daerah bilangan gelombang 3500-3400 $\mathrm{cm}^{-1}, 1600-1500 \mathrm{~cm}^{-1}$ serta $600-450 \mathrm{~cm}^{-1}$. Hal ini menandakan bahwa kitosan telah berinteraksi dengan partikel $\mathrm{ZnO}$ dan alumina. Hasil karakterisasi kristalinitas komposit menggunakan XRD juga menunjukkan adanya pergeseran sudut $2 \theta$ pada kitosan di $2 \theta 10^{\circ}$ dan $19^{\circ}$ yang mengindikasikan bahwa terjadi interaksi antara kitosan dengan partikel $\mathrm{ZnO}$ dan $\mathrm{Al}_{2} \mathrm{O}_{3}$.
\end{abstract}

Kata kunci : alumina, kitosan, komposit, spektra FTIR, XRD, ZnO

\begin{abstract}
The purpose of this research was to prepare novel composite based on biopolymer and nontoxic inorganic materials that can be applied for many uses such as coating agent on textile for antibacterial purposes. In this research, Chitosan- $\mathrm{ZnO} / \mathrm{Al}_{2} \mathrm{O}_{3}$ composites were prepared by mixing chitosan solution with $\mathrm{ZnO}$ particles and $\mathrm{Al}_{2} \mathrm{O}_{3}$ (alumina) sol produced by sol-gel method. The products were characterized with Fourier Transform Infra Red (FTIR) Spectrophotometer and X-Ray Diffractometer (XRD). The result of this research showed that composites exist as transparent solution that was suitable for coating agent application. The result of FTIR Spectrophotometer analysis showed that there were interactions between chitosan, $\mathrm{ZnO}$ particles and $\mathrm{Al}_{2} \mathrm{O}_{3}$ particles which indicated from absorption bands in the region of wave number $3500-3400 \mathrm{~cm}^{-1}, 1600-1500 \mathrm{~cm}^{-1}$ and 600 $450 \mathrm{~cm}^{-1}$. It mean that chitosan interacted to $\mathrm{ZnO}$ particles and alumina particles. The $\mathrm{XRD}$ analysis of composites showed that there were change in the diffraction peak in the 2
\end{abstract}


theta value of $10^{\circ}$ and $19^{\circ}$ which indicated interaction of chitosan with $\mathrm{ZnO}$ particles and alumina particles.

Keyword : Alumina, Chitosan, Composite, FTIR Spectra, ZnO, XRD

\section{PENDAHULUAN}

Perkembangan nano teknologi dan nano sains telah sedemikian pesat dan menjadi terdepan selama kurun waktu satu dasawarsa terakhir (Rajendran, et al., 2010). Nano teknologi menciptakan suatu struktur yang memiliki sifat yang unggul dengan mengontrol atom, molekul, material fungsional dan sistem pada skala nanometer (Kathirvelu, et al., 2009). Salah satu perkembangan nanoteknologi saat ini adalah nanokomposit yaitu nanokomposit organik-anorganik. Nanokomposit organik-anorganik merupakan gabungan dari biopolimer organik serta material anorganik yang memiliki sifat yang lebih baik dari masing-masing biopolimer organik maupun material anorganik sendiri (He, et al., 2002). Aplikasi nanokomposit organik-anorganik tersebar pada berbagai bidang seperti industri plastik, karet, fiber, pelapis (coating), tekstil dan industri lainnya dalam rangka meningkatkan sifat mekanik, termal dan optik seperti kekakuan, kelenturan dari suatu bahan (He, et al., 2002).

Beberapa penelitian nanokomposit yang telah dilakukan diantaranya adalah pembuatan komposit kitosan-silika untuk aplikasi biosensor glukosa oleh Saxena, et al. (2008) yang melaporkan bahwa komposit kitosan-silika sebagai membran pemisah protein memiliki selektifitas membran dan stabilitas dimensional yang lebih baik daripada membran kitosan. Hal ini dikarenakan adanya penggabungan dari kekuatan pengikatan serta stabilitas mekanik dan termal yang baik dari material anorganik serta reaktivitas kimia yang baik dari gugus fungsional pada material organik. Penelitian lainnya adalah pembuatan komposit kitosan-silika-paladium sebagai katalis hidrogenasi asetofenon dimana katalis kitosan-silika-paladium memiliki energi ikat yang lebih tinggi dibandingkan katalis paladium itu sendiri (Sun, et al., 2007). Mahltig, et al (2005) melakukan penelitian tentang penggunaan komposit silika kitosan sebagai pelapis tekstil sehingga menghasilkan tekstil antibakteri yang stabil terhadap pencucian. Penelitian Sun, et al (2007) tentang komposit Ag$\mathrm{SiO}_{2} / \mathrm{TiO}_{2}$ sebagai agen anti bakteri pada polimer dengan metode sol-gel juga telah dilaporkan. Oleh karena itu penelitian tentang pembuatan komposit untuk berbagai aplikasi menjanjikan performa yang lebih unggul.

Nano komposit kitosan-ZnOAlumina merupakan sebuah komposit dari gabungan material kitosan, nanopartikel $\mathrm{ZnO}$ dan alumina yang dibuat dan diaplikasikan sebagai bahan antibakteri pada tekstil. Kitosan dalam material komposit dapat membentuk stuktur lapisan (layer) pada partikel oksida anorganik seperti yang telah dilaporkan pada pembuatan katalis kitosan-Pt-SiO 2 yang dimungkinkan dapat berfungsi sebagai penghalang agglomerasi partikel $\mathrm{SiO}_{2}$ dan meningkatkan stabilitas kimia dari katalis komposit kitosan-Pt-SiO ${ }_{2}$ (Guibal, 2005). Penggabungan polimer kitosan dengan anorganik seperti silika, $\mathrm{ZnO}$ atau alumina dapat meningkatkan ketahanan abrasi kitosan pada kain (Farouk, 2012). Material $\mathrm{ZnO}$ memiliki aplikasi yang luas salah satunya diterapkan pada pelapisan tekstil karena memiliki sifat unik seperti sifat fotokatalitik, sifat anti UV, sifat antibakteri, sifat semikonduktor serta aman bagi manusia (Becheri, et al., 2008). Alumina juga memiliki aplikasi yang luas seperti pada tekstil, industri keramik, industri katalis heterogen, dapat berfungsi sebagai material abrasive, absorben, 
antibakteri, serta sebagai matriks pendukung pada material komposit (Shadiq, et al., 2009). Material alumina juga diketahui dapat meningkatkan ketahanan mekanik, termal dan meningkatkan sifat tahan api suatu bahan (Mahltig, et al., 2005). Material $\mathrm{ZnO}$ memiliki potensial zeta positif yang memungkinkan interaksi dengan permukaan material seperti selulosa dan biopolimer lainnya sehingga dapat digunakan untuk meningkatkan kekuatan mekanik dari biomaterial (Mahltig, et al., 2005).

Biopolimer organik yang banyak diteliti dalam kajian komposit salah satunya adalah kitosan. Kitosan merupakan turunan deasetilasi kitin dan merupakan polisakarida dengan kelimpahan terbesar kedua di alam setelah selulosa yang berasal dari cangkang udang atau kepiting (Fouda, et al, 2005). Kitosan sendiri merupakan polimer alam polikationik yang bersifat biodegradable, biocompatible, aman, tidak beracun, dapat membentuk film (lapis tipis) serta memiliki kemampuan adsorpsi (Al Sagheer and Muslim, 2010). Kitosan juga memiliki gugus fungsional amino yang sangat reaktif, bersifat sebagai antibakteri serta proses produksinya tidak memakan biaya yang besar (Farouk, et al., 2012). Dengan demikian penggunaan kitosan untuk aplikasi sebagai agen pelapis pada tekstil sangat menguntungkan untuk dilakukan. Melihat besarnya potensi partikel $\mathrm{ZnO}, \quad \mathrm{Al}_{2} \mathrm{O}_{3}$ serta biopolimer kitosan maka penelitian tentang material nanokomposit berbasis kitosan, material $\mathrm{ZnO}$ dan $\mathrm{Al}_{2} \mathrm{O}_{3}$ ini menjadi sangat penting untuk dikembangkan dan diteliti lebih lanjut.

Penelitian tentang pembuatan komposit berbasis kitosan dan nanopartikel oksida $\mathrm{ZnO}$ dengan crosslink silika untuk aplikasi agen antibakteri telah dilakukan oleh Farouk (2012). Hasil penelitian Farouk menunjukkan bahwa kemampuan penghambatan bakteri Staphyloco- ccusaureus oleh komposit kitosannanopartikel $\mathrm{ZnO}$ meningkat dibandingkan dengan kitosan. Hal ini disebabkan karena adanya nanopartikel yang tersebar pada polimer kitosan dengan crosslink silika dapat menurunkan berat molekul serta viskositas dari kitosan, sehingga aktivitas antibakterinya meningkat. Penelitian serupa juga dilakukan oleh AbdElhady (2012) yang melakukan sintesis komposit kitosan-nanopartikel $\mathrm{ZnO}$ sebagai agen antibakteri dan anti UV pada tekstil. Hasil penelitian menunjukkan bahwa aktivitas antibakteri kitosan-nanopartikel $\mathrm{ZnO}$ terhadap bakteri $S$. aureus dan Escherichia coli meningkat karena adanya penggabungan kemampuan penghambatan bakteri dari material kitosan dan sifat fotokatalitik $\mathrm{ZnO}$ (AbdElhady, 2012). Oleh karena itu pembuatan komposit kitosan$\mathrm{ZnO}$ menjanjikan hasil yang memuaskan dalam aplikasi sebagai agen pelapis dengan sifat antibakteri pada tekstil.

Berdasarkan penelitianpenelitian di atas, maka dalam penelitian ini akan dibuat komposit kitosan$\mathrm{ZnO} / \mathrm{Al}_{2} \mathrm{O}_{3}$ yang dipreparasi melalui pencampuran larutan kitosan dengan partikel $\mathrm{ZnO}$ dan sol alumina yang dibuat dengan metode sol-gel. Dalam penelitian ini digunakan material $\mathrm{Al}_{2} \mathrm{O}_{3}$ karena material alumina berfungsi untuk meningkatkan distribusi partikel $\mathrm{ZnO}$. Partikel $\mathrm{SiO}_{2}$ diketahui mudah mengalami agglomerasi (Leng, et al., 2007) sehingga akan menurunkan kemampuan untuk mendispersi partikel $\mathrm{ZnO}$ Komposit dikarakterisasi gugus fungsinya menggunakan spektrofotometer FTIR serta kristalinitasnya dengan XRD.

\section{METODELOGI PENELITIAN}

\section{Alat-alat Penelitian}

Alat-alat yang digunakan dalam penelitian ini antara lain satu set alat refluk, Erlenmeyer, gelas beker, hot plate stirer, pengaduk magnet, corong gelas, kertas saring, oven pemanas, neraca 
analitik, termometer, $\mathrm{pH}$ meter, labu ukur, pipet volum, pipet tetes, pengaduk spatula, furnice, sonicator dan sentrifuge.

\section{Bahan-bahan Penelitian}

Bahan-bahan yang digunakan dalam penelitian ini antara lain $\mathrm{HCl}$ p.a, asam asetat p.a, etanol $97 \%, \mathrm{ZnCl}_{2}$, alumunium isopropoksida $\left(\mathrm{Al}\left(\mathrm{OC}_{3} \mathrm{H}_{7}\right)_{3}\right)$, PVA, propanol serta aquades.

\section{Prosedur penelitian}

\section{Pembuatan larutan kitosan}

Larutan kitosan 1\% dibuat dengan cara melarutkan 1 gram kitosan ke dalam $100 \mathrm{~mL}$ larutan asam asetat $2 \%$ selanjutnya diaduk sampai larutan homogen (Maharani, et al, 2012).

\section{Pembuatan partikel ZnO}

Partikel $\mathrm{ZnO}$ dibuat dengan cara melarutkan $\mathrm{ZnCl}_{2}$ ke dalam air dan dipanaskan sampai temperatur $90 \quad{ }^{\circ} \mathrm{C}$ selama 10 menit, selanjutnya ditambahkan larutan $\mathrm{NaOH}$ dan didiamkan untuk memisahkan supernatan dan filtratnya. Supernatan dicuci dengan air sampai $\mathrm{NaCl}$ hilang. Selanjutnya supernatan ditambahkan dengan propanol kemudian dimasukkan dalam alat sonikator selama 30 menit. Larutan kemudian disentrifuge dan supernatan yang diperoleh dipanaskan dalam tanur pada temperatur $250{ }^{\circ} \mathrm{C}$ selama 5 jam (Maharani dan Rusmini, 2012).

\section{Pembuatan sol alumina}

Sol alumina dibuat dari alumunium isopropoksida $\left(\mathrm{Al}\left(\mathrm{OC}_{3} \mathrm{H}_{7}\right)_{3}\right)$. Sebanyak $0,5 \mathrm{~mL}\left(\mathrm{Al}\left(\mathrm{OC}_{3} \mathrm{H}_{7}\right)_{3}\right)$ dilarutkan dalam 97 $\mathrm{mL}$ etanol dan ditambah $2 \mathrm{~mL} \mathrm{HCl} 0,01 \mathrm{M}$ sebagai katalis selanjutnya ditambahkan PVA dan campuran homogen diaduk menggunakan magnetik stirer selama 24 jam pada temperatur ruang.

\section{Pemuatan komposit kitosan- $\mathrm{ZnO} / \mathrm{Al}_{2} \mathrm{O}_{3}$}

Pembuatan komposit kitosan-
$\mathrm{ZnO} / \mathrm{Al}_{2} \mathrm{O}_{3}$ dilakukan dengan cara

mencampurkan larutan kitosan, suspensi $\mathrm{ZnO}$ dalam air dan sol alumina dengan perbandingan $\% \mathrm{v} / \mathrm{v}=20: 80: 20$.

\section{HASIL DAN PEMBAHASAN}

\section{Karakteristik FisikaKimia Kitosan}

Larutan kitosan $1 \%$ sebagai prekursor komposit telah berhasil dipreparasi dengan cara melarutkan kitosan sebanyak 1 gram ke dalam $100 \mathrm{~mL}$ larutan asam asetat $2 \%$. Hasil yang diperoleh berupa larutan kitosan yang berwarna kekuningan jernih serta larut sempurna dan homogen. Larutan kitosan yang homogen ini sangat diperlukan dalam aplikasi seperti pelapis (coating agent) proses pelapisan pada kain, karena larutan yang homogen akan menghasilkan pelapisan yang merata, sempurna, dan tidak merubah warna bahan.

Kitosan sebagai salah satu prekursor dalam komposit terlebih dahulu dikarakterisasi gugus fungsional serta ditentukan harga derajat deasetilasi (DD) yang merupakan salah satu parameter penting untuk aplikasi kitosan. Hasil karakterisasi gugus fungsi kitosan menggunakan spektofotometer FTIR ditunjukkan pada Gambar 1.

Hasil analisis dengan spektrofotometer FTIR yang ditunjukkan pada Gambar 1 menunjukkan bahwa terdapat serapan gugus-gugus fungsional kitosan diantaranya yaitu serapan pada bilangan gelombang $3504,42 \mathrm{~cm}^{-1}$ yang menunjukkan vibrasi ulur gugus $\mathrm{OH}$, serapan dengan intensitas rendah di daerah 2923,88 $\mathrm{cm}^{-1}$ menunjukkan vibrasi simetris $\mathrm{CH}_{3}$, pada daerah1 $635,52 \mathrm{~cm}^{-1}$ dan 1542,95 $\mathrm{cm}-1$ yang menunjukkan vibrasi ulur gugus $\mathrm{C}=\mathrm{O}$ dan vibrasi tekuk gugus $\mathrm{NH}$ (Tan, et al., 2005). Serapan gugus-gugus fungsional kitosan tersebut telah menunjukkan karakter gugus fungsi kitosan dengan nilai derajat deasetilasi yang cukup baik. Berdasarkan perhitungan diperoleh harga DD menggunakan metode baseline adalah sebesar $79,15 \%$ yang 
menunjukkan kitosan yang digunakan sudah cukup baik (Standar DD kitosan adalah sebesar $>60 \%$ ).

Berdasarkan hasil analisis difraksi sinar X seperti ditunjukkan pada Gambar 2 diketahui bahwa kristalinitas kitosan yang digunakan dalam penelitian ini tidak terlalu tinggi atau cenderung amorf, yang menandakan bahwa kitosan tersebut sudah cukup baik karena tidak menunjukkan karakter kristalin kitin, yang didukung pula dengan data perhitungan derajat deasetilasi Kitosan menggunakan spektrofotometer
FTIR yang mencapai $79,15 \%$. Puncakpuncak karakteristik kitosan muncul pada $2 \theta 5-40^{\circ}$ yang merefleksikan bidang 020 , 110,101 , dan 130. Puncak pada sekitar $2 \theta$ $9^{\circ}$ merefleksikan bidang 020, sedangkan puncak pada $2 \theta 19,85^{\circ}$ merefleksikan bidang 110 , dan puncak pada $2 \theta 29,43^{\circ}$ merefleksikan bidang 130 (Zhang, et. al., 2003). Kitosan dengan karakteristik yang baik tersebut dimungkinkan dapat memberikan interaksi yang kuat antara gugus-gugusnya dengan dinding sel bakteri maupun partikel lainnya.

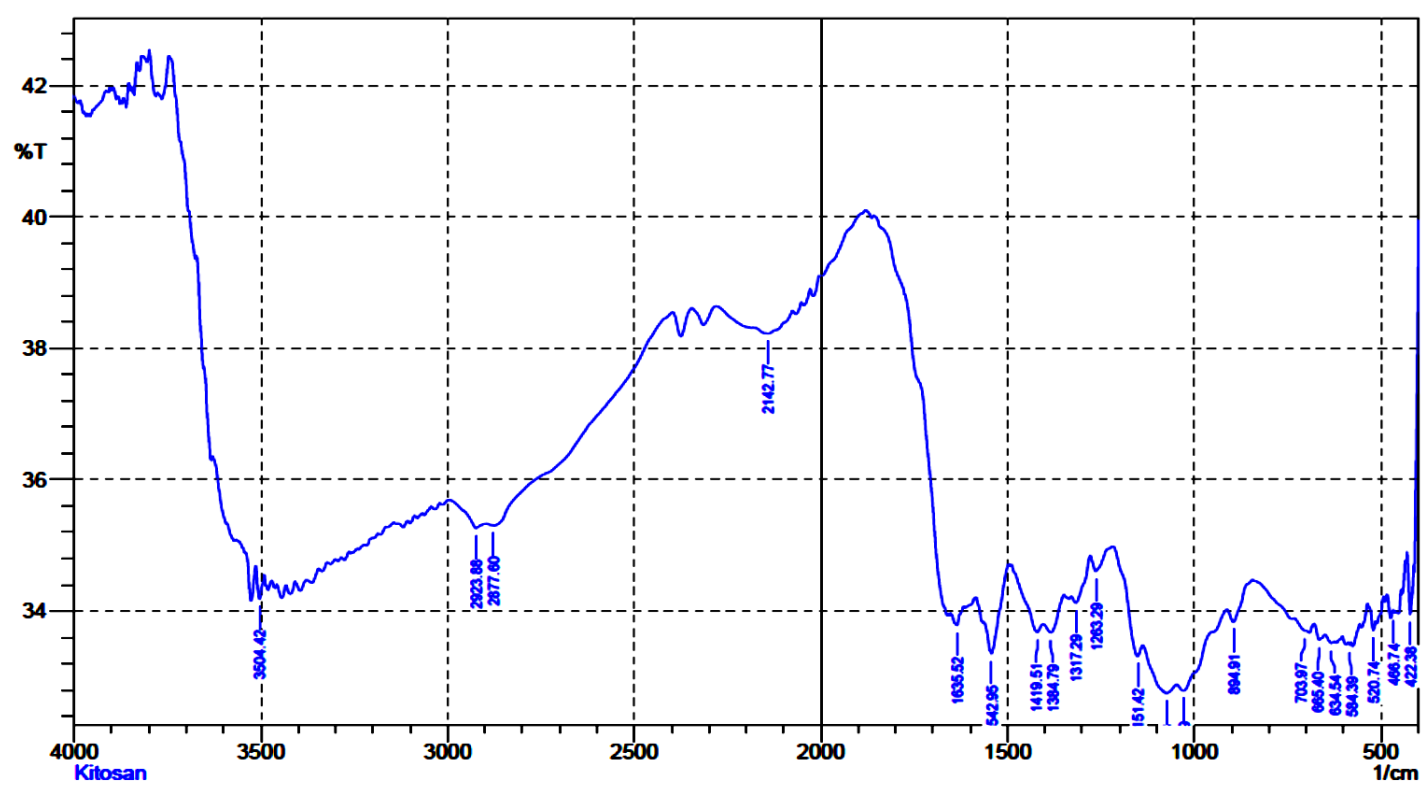

Gambar 1. Spektra FTIR kitosan

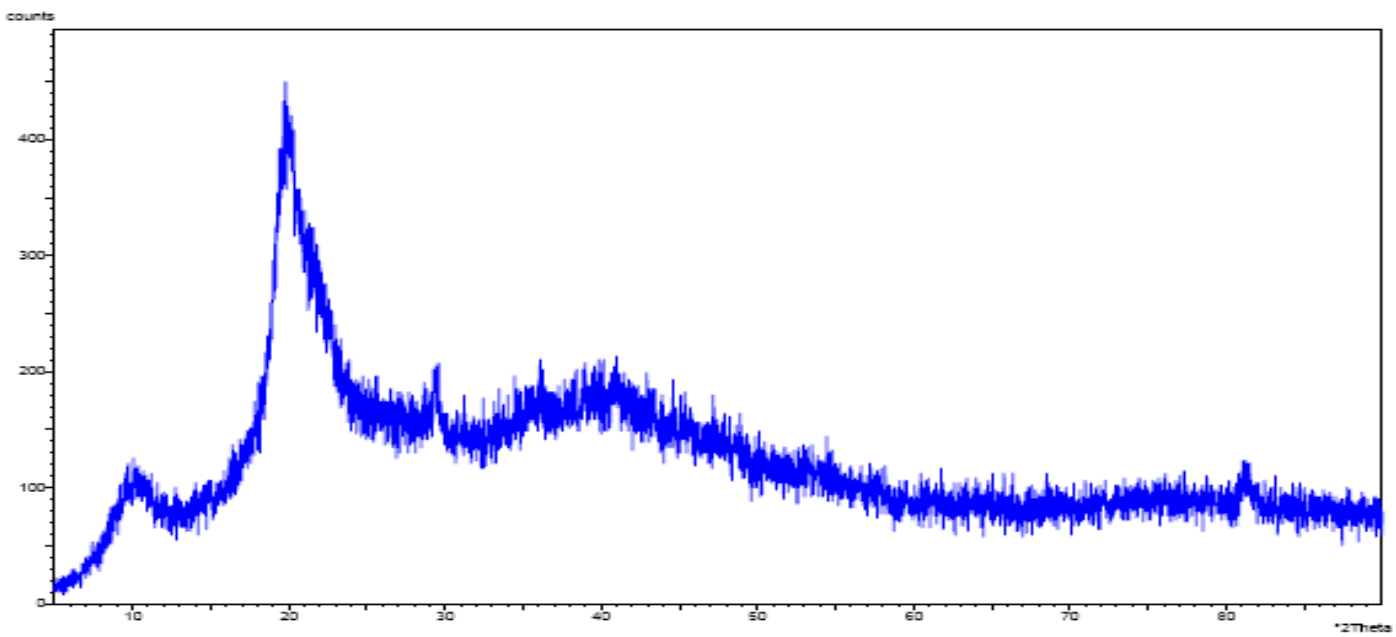

Gambar 2. Difraktogram Kitosan 


\section{Karakteristik fisika kimia partikel ZnO}

Partikel $\mathrm{ZnO}$ sebagai prekursor komposit juga telah berhasil dibuat dan menghasilkan serbuk berwarna putih. Warna putih ini merupakan warna khas dari padatan ZnO. Hasil karakterisasi kristalinitas partikel $\mathrm{ZnO}$ menggunakan XRD yang ditampilkan pada Gambar 3 menunjukkan telah terbentuk fasa kristalin $\mathrm{ZnO}$ yaitu muncul puncak pada $2 \theta 30^{\circ}$, $34^{\circ}, 36^{\circ}, 51^{\circ}$ dan $68^{\circ}$ (Becheri, et al., 2008) sehingga dapat disimpulkan bahwa partikel $\mathrm{ZnO}$ telah berhasil dipreparasi.
Karakterisasi terhadap partikel $\mathrm{ZnO}$ juga telah dilakukan dengan spektrofotometer FTIR. Spektra FTIR partikel $\mathrm{ZnO}$ pada Gambar 4 menunjukkan adanya serapan pada daerah bilangan gelombang $453 \mathrm{~cm}^{-1}$ yang merupakan serapan khas dari ikatan $\mathrm{Zn}-\mathrm{O}$. Serapan gugus fungsi pada daerah bilangan gelombang 600-400 $\mathrm{cm}^{-1}$ merupakan serapan khas dari gugus Zn-O (AbdElhady, 2012).

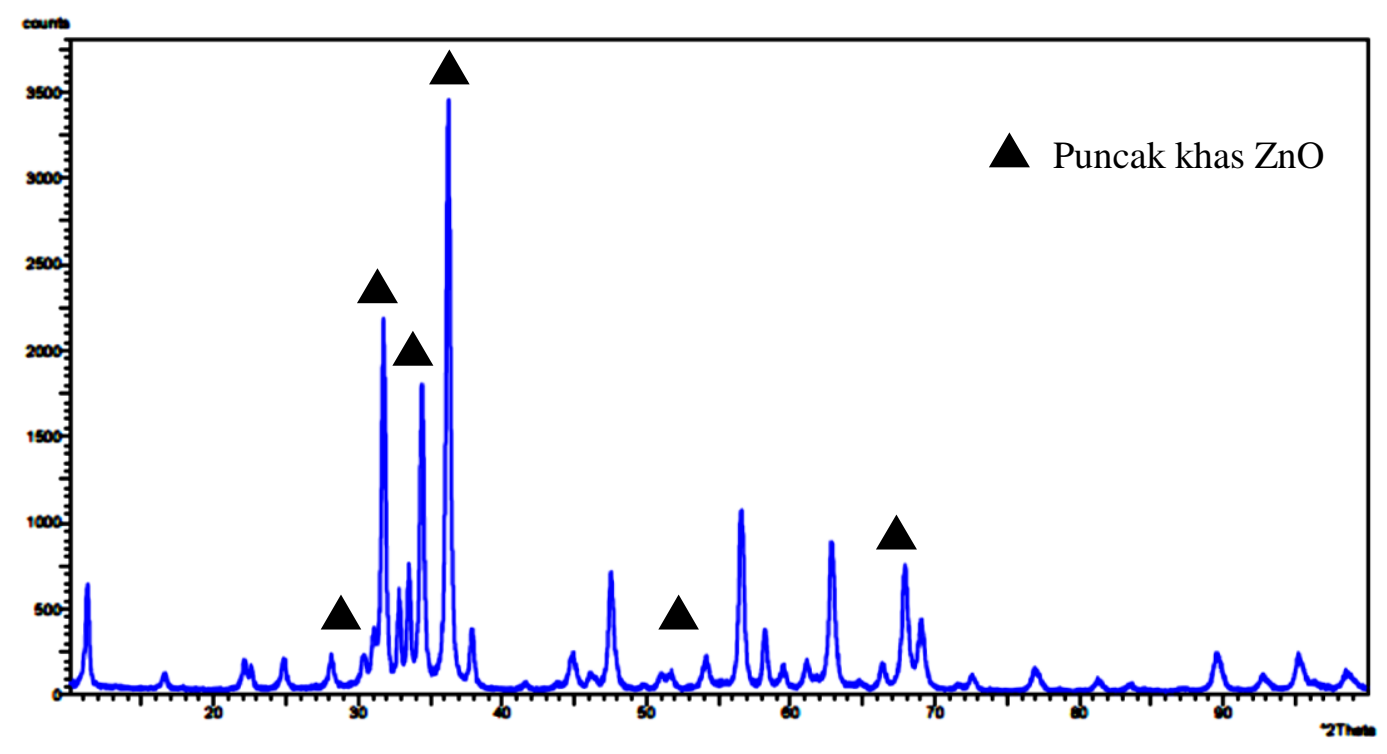

Gambar 3. Difraktogram partikel $\mathrm{ZnO}$

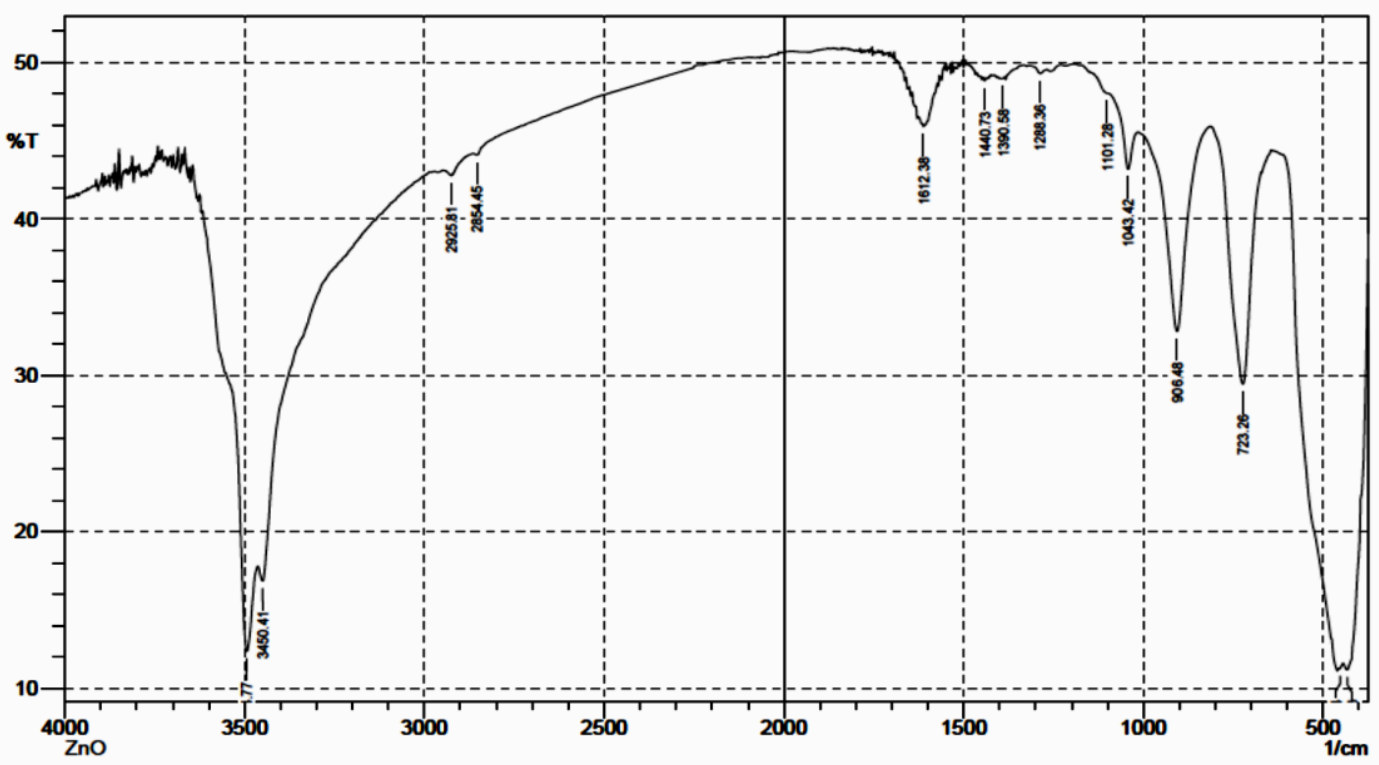

Gambar 4. Spektra FTIR ZnO 
Karakteristik komposit kitosan

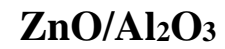

Komposit kitosan $\mathrm{ZnO} / \mathrm{Al}_{2} \mathrm{O}_{3}$ dikarakterisasi gugus fungsi maupun kristalinitasnya. Spektra FTIR pada Gambar 5 menunjukkan bahwa telah terjadi interaksi antara gugus fungsi pada kitosan dengan gugus fungsi pada $\mathrm{ZnO}$ dan alumina yang ditandai dengan pergeseran bilangan gelombang gugus fungsi pada kitosan di daerah 3500-3400 $\mathrm{cm}^{-1}$, 1600$1500 \mathrm{~cm}^{-1}$ serta daerah serapan gugus fungsi $\mathrm{ZnO}$ pada daerah sekitar 600-450 $\mathrm{cm}^{-1}$ (Salehi, et al., 2010). Pergeseran bilangan gelombang pada daerah bilangan $3504 \mathrm{~cm}^{-1}$ pada kitosan menjadi $3502 \mathrm{~cm}^{-1}$ pada komposit kitosan menunjukkan terjadinya interaksi antara gugus $\mathrm{NH}_{2}$ dengan $\mathrm{ZnO}$. Interaksi antar prekursor pada komposit kitosan $\mathrm{ZnO} / \mathrm{Al}_{2} \mathrm{O}_{3}$ juga terlihat kuat yang ditandai dengan pergeseran bilangan gelombang dari 1542 $\mathrm{cm}^{-1}$ pada kitosan menjadi $1550 \mathrm{~cm}^{-1}$ pada komposit kitosan $\mathrm{ZnO} / \mathrm{Al}_{2} \mathrm{O}_{3}$. Perubahan serapan yang terjadi tersebut menandakan bahwa partikel $\mathrm{ZnO}$ telah terintegrasi dengan kitosan.

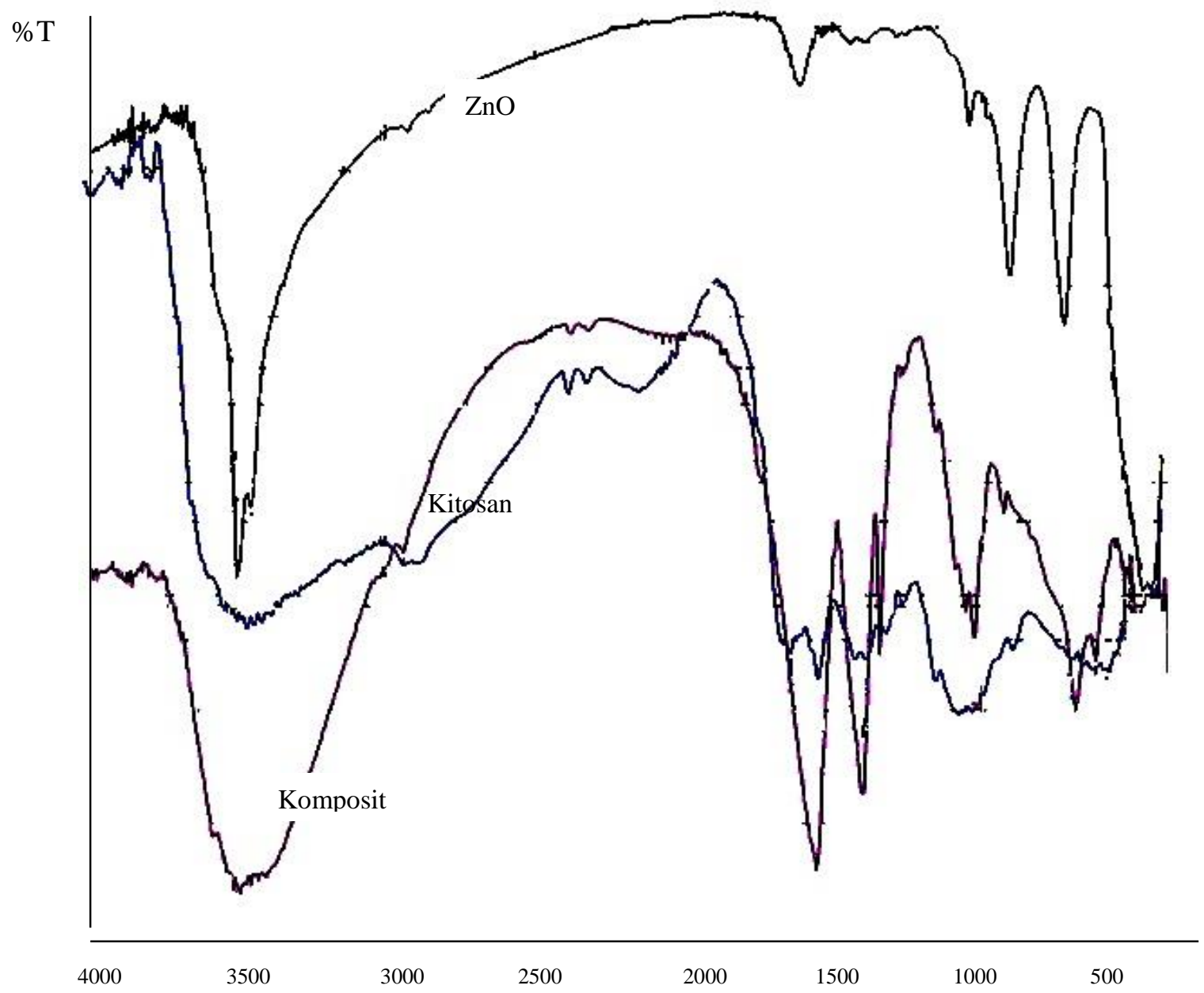

Gambar 5. Spektra FTIR komposit kitosan $\mathrm{ZnO} / \mathrm{Al}_{2} \mathrm{O}_{3}$

Hasil karakterisasi kristalinitas komposit kitosan $\mathrm{ZnO} / \mathrm{Al}_{2} \mathrm{O}_{3}$ seperti disajikan pada Gambar 6 menunjukkan adanya perbedaan yang cukup signifikan pada kristalinitas komposit kitosan $\mathrm{ZnO} / \mathrm{Al}_{2} \mathrm{O}_{3}$ dibanding dengan kitosan. 
Berdasarkan difraktogram pada Gambar 6 terlihat bahwa terdapat perbedaan terhadap kristalinitas serta kerapatan struktur komposit kitosan $\mathrm{ZnO} / \mathrm{Al}_{2} \mathrm{O}_{3}$ dan kitosan. Adanya distribusi nanopartikel $\mathrm{ZnO}$ dan alumina dalam kitosan menghasilkan kenaikan kristalinitas pada komposit kitosan- $\mathrm{ZnO} / \mathrm{Al}_{2} \mathrm{O}_{3}$ dibandingkan dengan kitosan. Hal ini juga mengindikasikan adanya partikel $\mathrm{ZnO}$ dan alumina yang terintegrasi dengan kitosan sehingga memunculkan pergeseran sudut puncak di $2 \theta 19,85^{\circ} ; 29,43^{\circ} ; 34,76^{\circ}$ pada kitosan menjadi $2 \theta 20,18^{\circ} ; 28,93^{\circ} ; 33,57^{\circ}$ pada komposit kitosan $\mathrm{ZnO} / \mathrm{Al}_{2} \mathrm{O}_{3}$. Terjadinya penurunan intensitas puncak khas kitosan pada daerah $2 \theta 10^{\circ}$ dan $19^{\circ}$ pada komposit kitosan $\mathrm{ZnO} / \mathrm{Al}_{2} \mathrm{O}_{3}$ menunjukkan bahwa terjadi perubahan kerapatan struktur kristalin kitosan akibat partikel $\mathrm{ZnO}$ dan alumina terintegrasi dengan kitosan. Partikel $\mathrm{ZnO}$ dan alumina yang terintegrasi pada komposit kitosan $\mathrm{ZnO} / \mathrm{Al}_{2} \mathrm{O}_{3}$ masih menghasilkan puncak-puncak karakteristik dari kedua material $\mathrm{ZnO}$ dan alumina. Puncak-puncak khas dari $\mathrm{ZnO}$ kristalin muncul pada daerah $2 \theta 30^{\circ}, 34^{\circ}, 36^{\circ}, 51^{\circ}$ dan $68^{\circ}$ dimana kitosan dalam ukuran mikro masih mendominasi puncak-puncak kristalin $\mathrm{ZnO}$ pada difraktogram komposit kitosan $\mathrm{ZnO} / \mathrm{Al}_{2} \mathrm{O}_{3}$. (AbdEhady, 2012).

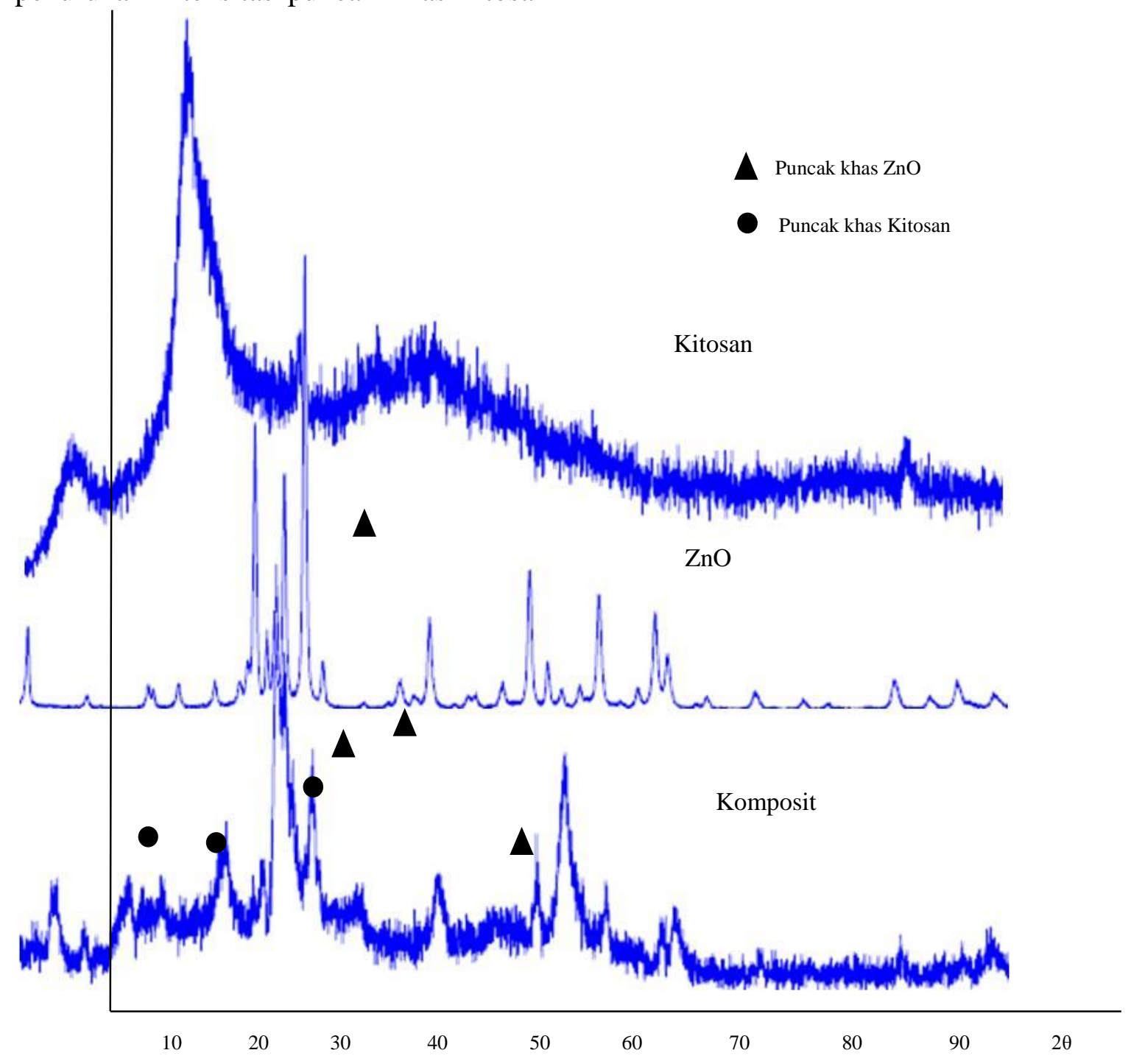

Gambar 6. Difraktogram komposit kitosan $\mathrm{ZnO} / \mathrm{Al}_{2} \mathrm{O}_{3}$ 


\section{KESIMPULAN}

Telah berhasil dilakukan sintesis komposit kitosan $\mathrm{ZnO} / \mathrm{Al}_{2} \mathrm{O}_{3}$ melalui metode sol-gel. Komposit yang dihasilkan berupa larutan yang jernih dan transparan sehingga sangat sesuai untuk aplikasi pada tekstil. Karakterisasi FTIR komposit menunjukkan telah terjadi interaksi antara kitosan dengan $\mathrm{ZnO}$ dan alumina yang ditandai dengan adanya pergeseran bilangan gelombang pada daerah 3500$3400 \mathrm{~cm}^{-1}, 1600-1500 \mathrm{~cm}^{-1}$ serta $600-450$ $\mathrm{cm}^{-1}$. Hasil karakterisasi kristalinitas komposit menggunakan XRD menunjukkan adanya penurunan puncak khas kitosan pada $2 \theta 10^{\circ}$ dan $19^{\circ}$ yang mengindikasikan bahwa kitosan telah terintegrasi dengan partikel $\mathrm{ZnO}$ dan alumina.

\section{DAFTAR PUSTAKA}

AbdElhady, M.M., 2012, Preparation, Characterization of Chitosan/ZnO Nanoparticles for Imp arting Antimicroial and UV Protection to Cotton Fabric, International Journal of Carbohydrate Composite, Vol. 2012

Al Sagheer, F and Muslim, S., 2010, Thermal and Mechanical Properties of Chitosan- $\mathrm{SiO}_{2}$ Hybrid Composites, Journal of Nanomaterial, Vol. 10 : 1-7.

Becheri, A., Durr, M., Nostro P., Bagliani, P. 2008. Synthesis and characterization of zinc oxide nanoparticles: application to textiles as UV-absorbers. Journal of Nanopart Research. Pp.679-689

Fouda, M.M.G., 2005, Use of Polysacharides in Medical Textile Applications, Dissertation, Universitat Duissburg-essen, Germany.

Farouk, A., M., 2012, ZnO NanoparticlesChitosan Composite as Antibacterial Finish for Textiles, International Journal of
Carbohydrate Chemistry, Vol. 2012

Guibal, E., 2005, Heterogeneous Catalysis on Chitosan-Based Materials: A Review, Prog. Polym Sci, Vol. 30, pp 71-109

He, Q., Wu, L., Gu, G., You, B., 2002, Preparation and characterization of acrylic/nano-TiO2 composite latex, High Performance Polymers, 14 : 383.

Kathirvelu,S., De Souza, S., and Durai, B., 2009, UV protection finishing of textiles using $\mathrm{ZnO}$ nanoparticles, Indian Journal of Fiber and Textiles Research, Vol. 34., 263279

Leng, P.B., Akil, H.M., and Lin, O.H., 2007, Thermal Properties of Microsilica and Nanosilica Filled Polypropylene Composite with Epoxy as Dispersing Aid, J. Reinf. Plast. Compos., 26, 761-770.

Maharani, D.K., Amaria, C., Rusmini, 2012, Preparasi dan Karakterisasi Komposit Kitosan-Silika Titania, Jurnal Manusia dan Lingkungan, Vol. 19, No. 1.

Maharani, D.K., dan Rusmini, 2012, Karakterisasi Komposit Kitosan $\mathrm{SiO}_{2} / \mathrm{ZnO}$ Secara Spektrofotometri IR dan Difraksi Sinar-X, Proseding Seminar nasional Kimia Unesa ISBN : 978-979-028-550-7

Mahltig, B., Haufe, H. dan Bottcher, H., 2005, Functionalisation of textile by Inorganic sol-gel coatings, $J$. Mater. Chem., Vol.15, 4385-4398.

Salehi, R., Arawi, M, Mahmodi, M.M., 2010, Novel Biocompatible Composite (Chitosan- $\mathrm{ZnO}$ Nanoparticles): Preparation, Characterization, dye adsorption properties, Colloid Surface B, Vol. 80, 86-93.

Saxena A., Tripathi, B.P. and. Shahi, V.K., 2008, An improved process for separation of proteins using modified chitosan-silica cross- 
linked charged ultrafilter membranes under coupled driving forces: Isoelectric separation of proteins, J. Colloid Interface Sci., 319, 252-262

Sun, B., Sun, S., Zhang, W., 2007, Preparation and antibacterial activities of Ag-doped $\mathrm{SiO} 2-\mathrm{TiO} 2$ composite films by liquid phase deposition (LPD) method, J. of Mater. Sci., Vol 42 : 10085-10089

Rajendran, R., Balakumar, C., Ahammed, H.A, Jayakumar, S, 2010, Use of zinc oxide nano particles for production of antimicrobial textiles, International Journal of Engineering, Science and Technology, Vol. 2, No. 1, 2010, pp. 202-208
Tan, X.C., Tian., Y., Cai, P. and Zou, X., 2005, Glucose biosensor based on glucose oxidase immobilized in sol-gel chitosan/silica hybrid composite film on Prussian blue modified glass carbon electrode, Anal. Bioanal. Chem., Vol. 381 : 500-507.

Zhang, Z, Chen, L., Ji, J.,Huang Y., Chen, D., 2003, Antibacterial Properties of Cotton Fabrics Treated with Chitosan, Textile Res. J.,. 73, 11031106. 